\title{
ON SOME ADDITIONAL LABYRINTHODONT FOSSILS FROM THE HAWKESBURY SANDSTONE OF NEW SOUTH WALES.
}

SECOND NOTE ON PLATYCEPS WILKINSONII.

By Professor Stephens, M.A., F.G.S.

The fossils which Mr. Wilkinson, Government Geologist, has had collected at Gosford, in the beds from which Platyceps Wilkinsonii, described in the last Volume of Proceedings, was obtained, were brought to Sydney at the beginning of this month of March.

The collection contains hundreds of specimens of fish, of many genera and families, among which is a possible Ceratodus, many Belonostomus of all sizes, Cleithrolepis, \&c., and many which are at present quite unknown to me. They are chiefly if not altogether Ganoids, and many quite new, at least to Australia. Some have been much broken in the quarry, others injured subsequently; but all were otherwise in a wonderful state of preservation. They had evidently been all killed at the same moment, and immediately buried. Some are quite straight and in their natural posture; others convulsed and distorted. One large fisb for example has the right pectoral fin thrown up on the same plane as the dorsal, with the underside of the head and fore quarter, and the right side of the rest of the body presented, showing both that the notochord was cartilaginous, and that the fish died suddenly in its struggles. Many others are twisted and bent double; and all seem to corroborate the speculation, advanced in a previous paper, that they were killed by a sudden influx of ice-cold nuud or muddy water into the tepid lagoon where they had been living. There are also with them beautifully preserved ferns, Phyllotheca and the like, which had evidently undergone no decomposition before they were silted up, but had been buried at once in the mud of the torrent which had torn them away. Besides the fish and vegetable remains there are also two Labyrinthodont remains; No. 1, almost entire, though not in good preservation, and No. 2, 
which gives an imperfect head, with some of the details in a good state. Example No. 1 is a little over a foot in length, broken off at the tail end, and apparently made up to some extent about the snout. For the collector, afraid that the soft and perishable nature of the stone might lead to the obliteration of important details, has applied a kind of black japan to the surface, doing no harm in some cases, but in others, as in this, quite destroying the outlines, which very probably were originally faint, or perhaps injured in the quarry. This renders the measurements from the snout doubtful, though they cannot be far out. The orbits are very distinct, and show that the fossil has been a little distorted by cownward and forvard pressure from the right, lying as they do to the other side of their true position, and with the right orbit a little in advance of and rounder than the left. The post orbital bones are in good relief, ending in acute angles towards the back of the head. A flattish medial depression in the parietals seems to indicate the place of the foramen, which may probably be determined by careful use of the knife, but which I cannot at present distinguish. The super-occipital is completely ossified, extending as far back as the anterior portion of the thoracic plates, and closing the intervening space shown in Vol. XI. pl. xxII. of our Proceedings. The quadrato-jugals are prolonged far to the rear of their position in the younger specimen, (ibid. p. 1182), and the branchial arches (if present) are obscurely indicated between these backward processes and the clavicular plates. The vertebral column is represented by an indistinct ridge extending about halfway down the whole length of the fossil, and pushed a little towards the left. I can see no traces of ribs, limbs, nor of any structure more than has been mentioned, except that the dermal covering of the head seems to be preserved, presenting an irregugularly pitted or granulated surface, the 'grain' averaging about $1 \mathrm{~mm}$. across. As in the former example, it is the inner or upper surface of the thoracic plates that is presented, and the outer or upper surface of the head.

It is curious that both this and the former specimen should have fared alike in this respect. Both of them preserve and expose the upper surface of the head, and both have lost all the structures overlying the Thoracic plates. The preservation of the head is no doubt owing to its more perfect ossification; and the 
stripping or disappearance of the dorsal region may I suppose be due to the cartilaginous condition of the notochord.

It is strange that no vestiges of limbs can be made out. But they may have been detached with the aforesaid dorsal structures, and escaped observation when the stone was split in the quarry.

No. 2, from the inversion of the orbit ring, which is deeply sunk, instead of projecting boldly as in the other specimens, appears to be a cast of the upper surface of the head. But the paint with which it has been covered renders it difficult to feel certain upon this point. Radiating sculpture marks the centres of four of the bones, but their sutures are not to be discovered. They may perhaps be the Maxillaries and Premaxillaries.

The principal measurements are as follows :-

Dimensions of Head.

Length.

Breadth

Distance of orbit from base of skull...... 15

Least width of interobital space ......... 10

Length of orbit............................ 13.5

Width

Distance of parietal foramen from base of skull................................ 12 ?

From centre of occiput to posterior end of orbit................................ 21

From tip of snout to anterior end of orbit

$$
\text { No. } 1 .
$$
Uncertain ; perh. about $65 \mathrm{~mm}$. Ditto, ditto 55 12

No. 2. perh. about $72 \mathrm{~mm}$. Ditto 62 Ditto 25?

Thoracic Plates. No. 1 only.

Medial. Length

Centre of radiating sculpture in advance of greatest breadth by... 7

Length of each anterior margin ................................... $\quad 32$

Length of each posterior margin ................................. 19

Laterals. Length from exterior angle (centre of radiation) to anterior margin................................................... 27

Transverse breadth of the whole set from angle to angle.......... 36

It is not absolutely certain that these two fossils belong to the same species as that first described. But they appear to show no other differences than such as are known to be brought about in other genera of Labyrinthodonts by length of life and increase in size; and I therefore, provisionally at any rate, regard them as the same. 


\title{
ADDITIONAL EVIDENCE ON FOSSII، SALISBURIA
}

\author{
FROM AUSTRALIA.
}

\author{
By F. Ratte, M.E.
}

Jeanpaulia (?) palmata, Ratte, Proc. Linn. Soc. N.S.W., Vol. I. (ser. 2), p. 1078; Salisburia palmata, Ratte, emend. from Jeanpaulia or Baiera palmata, Ibid. Vol. II. (ser. 2), p. 137.

After the last meeting of the Society, when I suggested that the large palmate leaf found in the shale of the WianamattaHawkesbury formation, should be referred to the genus Salisburia, I unexpectedly found in the French weekly paper "La Nature," an interesting contribution on the subject, by Marquis G. de Saporta.

From that paper and the woodcuts given, I find that this author, and also Professor Heer of Zurich, give the name of Salisburia to a number of plants with coriaceous and persistent leaves, which, for the sake of giving a brief outline of their characters and distribution, I will enumerate as follows :-

\begin{tabular}{|c|c|c|c|}
\hline$=$ & LOCALITY. & JURASSIC. & Cretackous. \\
\hline $\begin{array}{l}\text { a. Leaf entire, rhomboidal (transver- } \\
\text { sally). } \\
\text { SALISBURIA ANTARCTICA. Sap........ } \\
\text { b. Leaf entire, reniform. } \\
\text { SALISBURIA PRIMORDIALIS. Hr...... } \\
\text { c. Leaf fan-shaped, with only a few } \\
\text { incisions. }\end{array}$ & $\begin{array}{l}\text { Australia... } \\
\text { S. Greenland }\end{array}$ & $\begin{array}{c}\text { Lower Lias? } \\
\ldots \ldots\end{array}$ & Chalk \\
\hline Salisburia integriuscula. Hr.... & $\begin{array}{l}\text { Cape Bohe- } \\
\text { man (Spitz- } \\
\text { berg) }\end{array}$ & Jurassic & $\ldots \ldots$ \\
\hline
\end{tabular}


d. Leaf confusedly quadrangular, irregularly, not deeply sinuated, divisions broad, irregularly rounded at the apex.

Salisburia digitata (Brngt.) Hr.

e. Leaf distinctly divided into twoprincipal symmetrical segments, more or less sinuated.

Salisburia Huttoni (Sternbg.) Hr. S. PSEudo-Huttoni (Hr.) Sap.....

f. Leaf palmate; divisions numerous, deep, oval, rather broad; secondary sinuations not very deep. Apices rounded or rather acute ( $S$. Schmidtiana).

Salisburia Pluripartita. Schimp.

S. ARCTICA. Hr.

S. Schmidtiana.

$\mathrm{H}$

g. Leaf palmate; divisions numerous, deep, oval, elongate; secondary divisions deep. A Apices rather more acute than rounded.

Salisburia flabellata. Hr......

S. LEPIDA. Hr......................
h. Leuf palmate; divisions numerous, digitiform, broad, rounded at the apex.

Salisburia sibirica. Hr.

S. Sibirica var. PUsilla (Hr.) Sap.

k. Leaf palmate; divisions numerous, digitiform, narrow. A pex rounded

SALISBURIA CONCINNA.

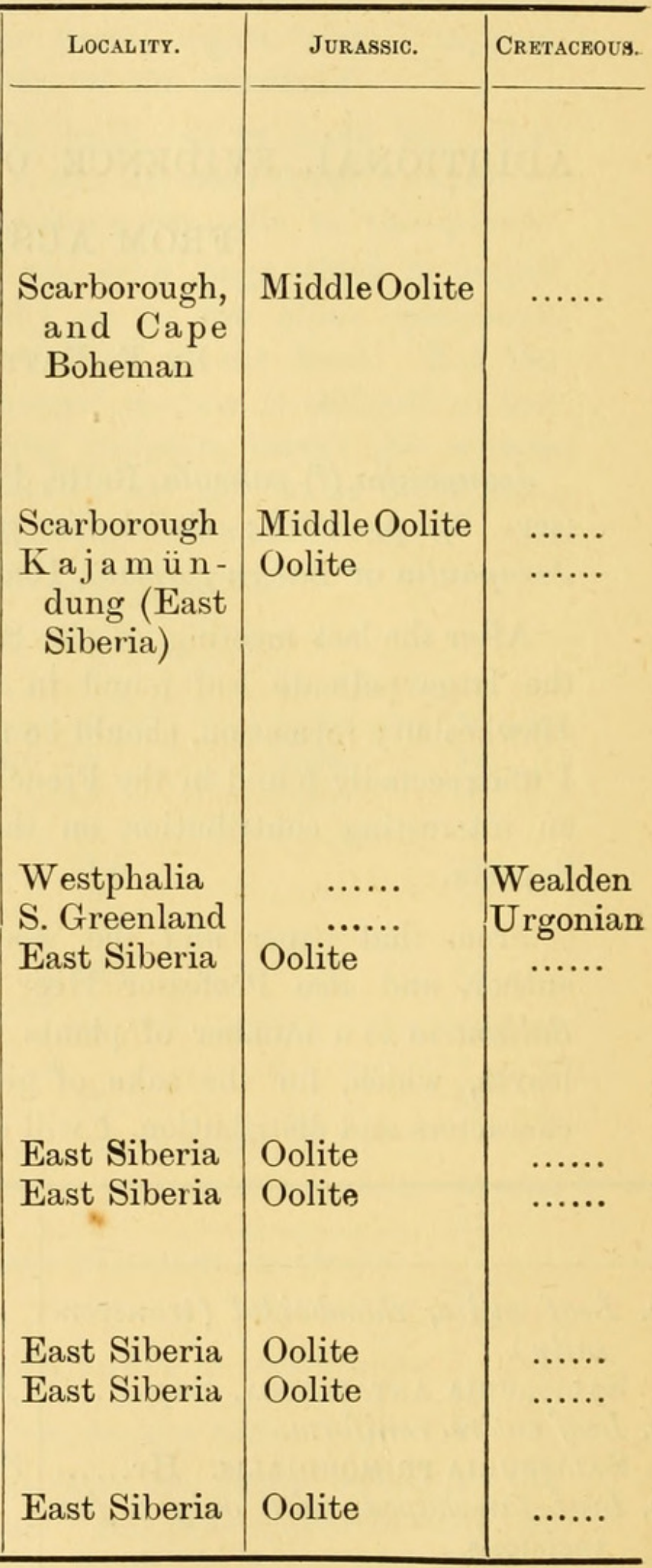

The last two forms are most nearly related to our fossil. But even now, after this fresh evidence, the generic affinity does not seem perfectly clear. There are, besides Baiera, other genera 
(Phoenicopsis, Trichopitys, and Czekanowskia), allied to Salisburia, about which I have no literature at hand; and Marquis de Saporta, in the above-mentioned contribution, (1) even doubts whether Salisburia concinna of Professor Heer, is really a Ginkgo, as its resemblance with the genus Baiera, might, according to this author, be due to a recurrence of form appearing in distinct and parallel groups, originally issued from a common ancestral stock.

I will not follow the author in his sketch of the affinities and migrations of the different species; I will simply quote, without translating, any paragraph dealing with the Australian fossil, Salisburia antarctica, or tracing the genus further back than our triassic species.

At the same time, as a matter of reference, it will not probably be out of place to mention that Mr. Feistmantel has described three species from the Gondwana series (Foss. Flora Gondwana, Vol. IV. p. 49, pl. III. \&c.)

Now, from Marquis de Saporta, I give the following extracts :

“ Un fait singulier est venu dévoiler récemment l' existence à l' autre extrémité du globe, sur le sol australien, d' un quatrième point alors habité par le même genre Salisburia. Le moment précis de cette colonisation, indice d'une très-vaste diffusion antérieure due à la grande longevité du type, ce moment doit être rapporté au lias ou même au lias inférieur. On voit par la qu' à l' exemple des Araucaria dans le passé et conformément à ce que le hêtre (fagus) nous laisse voir maintenant, les Salisburia étaient répandus à la fois dans les deux hemisphères, vers le milieu des temps secondaires, et qu'ils s' étendaient au-delà du tropique du Capricorne, aussi bien qu' à l'intérieur du cercle polaire arctique." (Loc. cit. p. 157.)

And further :-

"L'Australie a fourni une seule espèce, que nous nommerons Salisburia antarctica." (Loc. cit. p. 203.)

This Australian species thus, it appears, comes back to us indirectly, and is still unpublished at the time de Saporta writes;

(1) G. de Saporta. Les Variations morphologiques d'un type de Plantes. "La Nature" 26 Août 1882, p. 203. 
he only figures it (loc. cit. p. 204); and I think it belcngs to the Proceedings to have it represented ; I therefore give a drawing of it (Plate III). The author does not state where his specimen comes from, and more light on the subject will be highly interesting.

However our Salisburia palmata, if it ought to be considered as such, is not the oldest of its genus, as de Saporta has named Salisburia primigenia, a plant discovered by Professor Grand' Eury in the Middle Permian of Jelovick, near Tchoussovskaiä, in the Urals; about which discovery he says :-

"Jusqu'ici les Gingkos ne dépassaient pas le rhétique, dans la direction du passé (in the past). En Europe le Salisburia crenata (Brauns) Nath., et, en Australie, le Salisburia antarctica, Sap., espèce encore inédite, marquaient les derniers jalons (land marks) qui aient été signalés." [Sur quelques types de végétaux récemment observés a l'état fossile. M. G. de Saporta, in Comptes Rendus Acad. Sciences, 1r. Semestre, 1882, page 922.]

Before ending this note I beg leave to point out the importance, for our geolngical record, of ascertaining the precise locality whence Salisburia antarctica, Sap. comes. Some clue to it might be found in Rev. T. Woods's elaborate paper on "The Coal Plants of Australia," as he places the Burnett River beds, where already Jeanpaulia (Baiera) bidens, T. Woods, has been found, as Infralias or Lower Lias (?) with a query. 


\section{ON AN UNDESCRIBED SHARK FROM PORT JACKSON.}

By E. Pierson Ramsay, F.R.S.E., \&c., and J. Douglas-Ogilby.

\section{Carcharias macrurus, n. sp.}

Form rounded, moderately tapering. Snout of moderate length, obtuse, thickly studded with minute pores. Eyes rather nearer to the end of the snout than to the anterior gill-opening. Cleft of mouth deep, its gape wide. A short, but deep groove behind the angle of the mouth. Nostrils obliquely transverse, much nearer to the mouth than to the tip of the snout. Teeth in both jaws serrated, in the upper oblique with the base swollen; erect and smaller in the lower jaw. First dorsal fin situated much nearer to the tip of the srout than to the base of the caudal, and closer to the end of the base of the pectoral than to the origin of the ventral : second dorsal one-third of the size of the first; the space between the dorsal fins being rather more than one-third of the distance between the end of the second and the base of the caudal : pectorals large and falciform, reaching to beneath the end of the first dorsal, its inner lobe two-ninths of the end of the outer. Ventrals small with the lower margin truncate. Caudal with basal pit above and below, its upper lobe one-fourth of the total length, and notched near the extremity. Skin rough. Colorsabove plumbeous, below white; tips of second dorsal, lower caudal lobe, and pectorals, black.

\section{Measurements :-}

Total length

Depth at origin of first dorsal fin

Depth at root of caudal fin

Circumference of body ...

Breadth of body 


\section{Measurements-continued :-}

Breadth of head immediately in front of gill-openings, nearly

Breadth of snout immediately in front of eyes, nearly $\ldots \quad 3_{2}^{1}$

$\begin{array}{llllllll}\text { Interorbital space } & \ldots & \ldots & \ldots & \ldots & \ldots & \ldots & 3_{3}^{1}\end{array}$

Distance between tip of snout and mouth $\quad \ldots \quad \ldots \quad \ldots \quad 2_{4}^{3}$

Distance between tip of snout and nostril, nearly $\quad \ldots \quad 2$

Distance between tip of snout and eye, nearly $\ldots \quad \ldots \quad \ldots \quad 3$

$\begin{array}{llllll}\text { Distance between nostril and mouth } & \ldots & \ldots & \ldots & 1_{3}^{1}\end{array}$

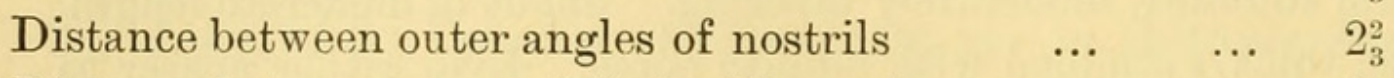

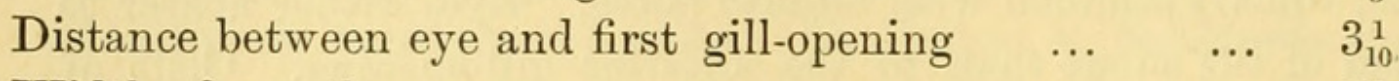

$\begin{array}{llllllll}\text { Width } \text { of mouth } & \ldots & \ldots & \ldots & \ldots & \ldots & \ldots & 2_{4}^{3}\end{array}$

$\begin{array}{lllllllll}\text { Depth of mouth } & \ldots & \ldots & \ldots & \ldots & \ldots & \ldots & 1_{5}^{2}\end{array}$

Origin of first dorsal to the end of the base of pectoral $\ldots \quad 5_{10}^{1}$

End of first dorsal to the origin of ventral $\quad \ldots \quad \ldots \quad \ldots \quad 5_{5}^{3}$

$\begin{array}{llllllll}\text { Outer edge of pectoral } & \ldots & \ldots & \ldots & \ldots & \ldots & 5_{2}^{1}\end{array}$

$\begin{array}{llllllll}\text { Inner edge of pectoral } & \ldots & \ldots & \ldots & \ldots & \ldots & 1_{4}^{1}\end{array}$

$\begin{array}{lllllllll}\text { Intradorsal space } & \ldots & \ldots & \ldots & \ldots & \ldots & \ldots & 8_{5}^{1}\end{array}$

$\begin{array}{lllllllll}\text { Diameter of eye } & \ldots & \ldots & \ldots & \ldots & \ldots & \ldots & 1\end{array}$

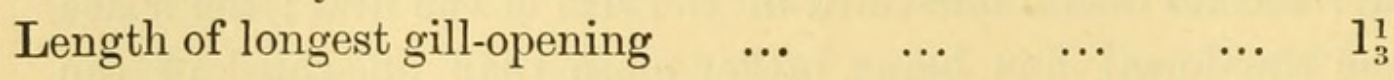

This Shark is said to be not uncommon on the New South Wales Coast, where it is called the "Whaler," and has been hitherto confounded with Dr. Günther's Carcharias brachyurus, from which however it may be recognised at a glance by the shape of the mouth and the obtuseness of the snout. Type specimen in Australian Museum, I. 1155. 
LIST OF BIRDS COLLECTED AT DERBY, NORTH WEST AUSTRALIA, BY THE LATE T. H. BOYER-BOWER, EsQ., WITH NOTES.

By Dr. E. P. Ramsay, F.R.S.E., \&c., \&c.

(Continued from Vol. I. (2nd ser.) p. 1100.)

1. Gypoictinia melanosternon, Gould.

One specimen similar to the eastern form of this species.

2. Falco lunulatus, Latham. (Falco frontatus, Gould).

One specimen is a rich slate-blue on the upper surface, and below has a deeper orange rufous tint than I have observed in any of the N.S. Wales examples.

3. Circus assimilis, Jard. \& Selb.

(Circus jardinii, Gould).

4. Circus gouldit, Bonp.

(Circus assimilis, Gould).

5. Astur approximans, Vig. \& Horsf.

Quite similar to the N. S. Wales examples.

6. Astur cruentus, Gould.

These are the first examples I have seen of this species, which is undoubtedly a very distinct form from A. approximans; in plumage it closely resembles Accipiter cirrhocephalus.

Total length male 13.5 in., wing 9.3 in., tail 7 in., tarsus 2.7 in. ; first joint of mid-toe 0.55 in. Female 15.5 in., wing 10 in., tail 8.5 in., tarsus 2.9 in. ; first joint of mid-toe 0.7 in. 
7. Accipiter cirrhocephalus, Vieill.

(A. torquatus, Gould).

Similar to N. S. Wales specimens.

8. Haliastur indus, Vieill.

Var. GIRRENERA, Sharpe.

9. Haliastur sphenurus, Vieill.

10. Milvus affinis, Gould.

11. Falco melanogenys, Gould.

12. Hieracidea occidentalis, Gould.

13. Hieracidea orientalis, Schl.

(H. berigora, (Gray).

14. Tinnunculus cenchroides, Vig. \& Horsf.

15. Pandion leucocephalus, Gould.

16. Strix delicatula, Gould.

17. Ninox connivens-occidentalis, Rams.

See P.L.S. N.S.W., Vol. I. (second series), p. 1086.

18. Agotheles leucogaster, Gould.

This bird is very variable in its tints of plumage, especially on the upper surface.

19. Podargus gouldi, Masters.

Ramsay, P.L S. N.S.W., Vol. I. (2nd series), p. 1097.

20. Eurostopodus guttatus, Vig. \& Horsf.

Ramsay, P.L.S. N.S.W., Vol. I. (2nd series), p. 1097.

21. Merops orna its, Lath.

22. Eurystomus pacificus, Lath.

23. Dacelo cervina, Gould.

24. Halcyon macleayi, Jard. \& Selb.

25. Halcyon pyrrhopygius, Gould.

This bird seems to be universally dispersed over the whole of Australia. 
26. Artamus cinereus, Vieill.

27. Cracticus picatus, Gould.

28. Cracticus robustus, Lath.

(C. nigrogularis, Gould).

29. Graucalus melanops, Lath.

30. Artamus minor, Vieill.

31. Artamus leucopygialis, Gould.

32. Pardalotus uropygialis, Gould.

33. Cracticus torquatus, Lath.

(Barita destructor, Temm.)

34. Campephaga tricolor, Swains.

35. Pachycephala falcata, Gould.

36. Collyriocincla brunnea, Gould.

37. Collyriocincla rufigaster, Gould.

38. Rhipidura preissi, $C a b$.

39. Rhipidura setosa, Quoy et Gaim.

40. Sauloprocta picata, Gould.

41. Seisura nana, Gould.

42. Myiagra concinna, Gould.

43. Myiagra latirostris, Gould.

The one specimen obtained appears to be Gould's $M$. latirostris, but may hereafter prove to be only a female of $M$. concinna.

44. Gerygone albogularis, Gould.

Ramsay, l.c. p. 1098.

45. Smicrornis flavescens, Gould.

46. Petreca picata, Gould.

47. Peecilodryas cerviniventris, Gould.

Notwithstanding that several specimens were obtained, this bird does not appear to be common anywhere. Ramsay, l.c. p. 1089. 
LIST OF BIRDS COLLECTED AT DERBY, NORTH WEST AUSTRALIA,

48. Malurus cruentatus-boweri, Ramsay.

(? Malurus cruentatus, Gould ; juv.)

49. Malurus coronatus, Gould.

Many specimens of this beautiful species were obtained during the months of September and October; judging from some young individuals they must have been breeding as early as June. During the first year the young males resemble the females in plumage with the exception of the ear-coverts.

50. Malurus lamberti, Lath.

These appear to be identical with the New South Wales birds.

51. Cisticola ruficeps, Gould.

52. Cisticola sp. (? C. lineocapilla, Gould.)

53. Ephthianura crocena, Castl. \& Rams.

This species extends as far eastwards as the Gulf of Carpentaria, where it was originally obtained by Mr. Gulliver during his travels in that district.

54. Cincloramphus cruralis, Vig. \& Horsf.

55. Cincloramphus cantillans, Gouid.

See previous remarks on these species. Ramsay, l.c. p. 1098.

56. Ptencedus rufescens, Vig. and Horsf.

57. Mirafra horsfieldit, Gould.

58. Calamoherpe longirostris, Gould.

59. Estrildda BichenoviI, Vig. \& Horsf.

60. Estrilda annulosa, Gould.

61. Estrildi castanotis, Gould.

62. Estrilda ruficauda, Gould.

63. Estrilda phaeton, Homb. \& Jacq.

64. Donacicola pectoralis, Gould.

This bird was found to be plentiful near Port Darwin; Mr. Gulliver also obtained specimens in the Gulf District. 
65. Poephila acuticauda, Gould.

Plentiful, many live specimens being also obtained.

66. Poephila gouldie, Gould.

67. Poephila mirabilis, Homb. \& Jacq.

See previous remarks, l.c. p. 1091.

68. Chlamydodera nuchalis, Jard. \& Selb. Females only obtained.

69. Pomatostomus rubeculus, Gould.

70. Stigmatops subocularis, Gould.

71. Sitigmatops ocularis, Gould.

72. Ptilotis vittata, $C u v$.

73. Ptilotis flavescens, Gould.

74. Ptilotis notata, Gould.

75. Stomiopera unicolor, Gould.

This bird was originally obtained at Port Essington; it has a wide range extending over the whole of the north, and northwestern portions of the Continent.

76. Entomophila albogularis, Gould.

77. Entomophila rufogularis, Gould.

78. Philemon argenticeps, Gould.

79. Philemon, juv. (sp. ?)

80. Mrzomela pectoralis, Gould.

81. Melithreptus albogularis, Gould.

82 Melithreptus letior, Gould.

83. Myzantha lutea, Gould.

84. Diceum hirundinaceum, Shaw.

Universally dispersed over the whole Continent.

85. Climacteris melanura, Gould. 
170 LIST OF BIRDS COLLECTED AT DERBY, NORTH WEST AUSTRALIA,

86. Sittella leucoptera, fould.

87, Cuculus dumetorum, (?) Gould.

88. Cacomantis Pallida, Lath.

(Cuculus inornatus, Gould).

89. Cuculus flabelliformis, Lath.

90. Mesocalius palliolatus, Lath.

(Chalcites osculans, Gould).

91. Chalcites basalis, Horsf.

92. Chalcites minutillus, Gould.

93. Eudynamis cyanocephala, Lath.

(E. flndersi, Gould).

94. Centropus melanurus, Gould.

Probably only a variety of $C$. phasianus, Latham.

95. Cacatua gymnopis, Sclater.

96. Cacatua roseicapilla, Vieill.

97. Calyptorhynchus stellatus, Wagl.

(C. macrorhynchus, Gould).

98. Calyptorhynchus naso, Gould.

99. Calopsittacus nove hollandie, Gmel.

100. Ptistes coccineopterus, Gould.

101. Trichoglossus rubritorquis, Vig. \& Horsf.

102. Trichoglossus versicolor, Vigors. 
103. Phaps histrionica, Gould.

104. Lopophaps ferruginea, Gould.

This bird was found in immense numbers during the month of October, 1886.

105. Ocyphaps lophotes, Temm.

106. Phaps chalcoptera, Lath.

107. Geopelia humeralis, T'emm.

108. Geopelia placida, Gould.

109. Stictopelia cuneata, Lath.

110. Synoicus australis, Lath.

111. Hemipodius velox, Gould.

112. Edicnemus grallarius, Lath.

113. Lobivanellus miles, Bodd.

114. Agialitis geoffroyi, Wagler.

(Hiaticula inornata, Gould).

115. Agialitis nigrifrons, Cuv.

116. Erythrogonys cinctus, Gould.

117. Actitis empusa, Gould.

118. Scheniclus albescens, Temm.

119. Limnocincla acuminata, Horsf.

120. Glareola grallaria, Temm.

121. Totanus sP.

122. Recurvirostra rubricollis, Temm. 
172 LIST OF BIRDS COLLECTED AT DERBy, NORTH WEST AUSTRALIA.

123. Himantopus leucocephalus, Gould.

124. Glottis Glottoides, Linn.

125. Gallinago australis, Lath.

126. Geronticus spinicollis, Jameson.

127. Threskiornis strictipennis, Gould.

128. Platalea regia, Gould.

129. Xenorhynchus australis, Lath.

130. Ardea pacifica, Lath.

131. Ardea nove-hollandie, Lath.

132. Herodias alba, Linn.

133. Herodias melanopus, Wagl.

(A. garzetta, Linn.)

134. Herodias intermedia, $V$. Hasselq.

(H. plumiferus, Gould).

135. Nycticorax caledonicus, Lath.

136. Butoroides flavicollis, Lath.

137. Porphyrio bellus, Gould.

138. Tribonyx ventralis, Gould.

139. Fulica australis, Gould.

These birds should be compared with a series of South-east Australian specimens; there are probably two distinct species.

140. Tadorna radjah, Garnot. 
141. Anas castanea, Eyton.

142. Chlamydochen Jubata, Lath.

143. Nettapus pulchellus, Gould.

144. Dendrocygna vagans, Eyton.

145. Malacorhynchus membranaceus, Lath.

146. Podiceps gularis, Gould.

147. Podiceps australis, Gould.

148. Sterna anglica, Mont.

(Gelohelidon macrotarsa, Gould).

149. Sterna frontalis, Gray.

(Sterna melanorhyncha, Gould).

150. Plotus nove hollandie, Gould.

151. Graculus melanoleucus, Vieill.

152. Graculus stictocephalus, $B p$. 


\section{NOTES AND EXHIBITS.}

Mr. Norton exhibited a specimen of one of the Myxomycetes, identified by Mr. Whitelegge as Stemonitis fusca, or ferruginea, Ehrenb., found on the trunk of a tree at Springwood.

Mr. Wilkinson exhibited a selection from the Gosford Collection of Fossils, now amounting to about 400 specimens, comprising a number of new and remarkable forms of Fishes, and he pointed out the importance of the evidence which is now accumulating in favour of the view that the Hawkesbury formation is of Triassic age.

Dr. Ramsay exhibited (1.) An Egg of the Top-knot Pigeon Lopholaimus antarcticus, (Shaw), taken from the oviduct by Mr. McLennan. The egg is nearly perfectly oval, being only slightly pointed at the thin end, white, and without any gloss; length $1.85 \times 1.25$ inches; (2.) Some very old diorite Stone Hatchets used by the Aborigines of the Lachlan district, where they were obtained by Mr. K. H. Bennett of Mossgiel ; (3.) Flint-flakes used by the Aborigines of Tasmania; (4.) Slabs of Shale with Fossil Ferns (Rhacopteris, \&c.), from near Stroud, N.S.W.

Mr. Palmer exhibited six silk egg-bags made by the same spider (species uncertain) at different times, and attached to a branch.

Mr. Masters exhibited a living specimen of one of the "Sleeping Lizards" Cyclodus nigro-luteus, Q. and G., sent by Mr. J. D. Cox from Mt. Wilson-a species which is rare so far north, though common in Victoria and Tasmania.

Mr. Steel exhibited a specimen of Bombyx from Fiji, quite overgrown by a fungus, springing from all parts of the body.

Mr. Ogilby exhibited a living example of a rare Toad, Notaden Bennettii, Gunth., recently forwarded from Cobar to the Australian Museum. Also an example of the rare snake Brachyurophis australis, Krefft, hitherto only recorded from the Clarence and Burdekin Rivers. The locality of the present specimen is unknown. 
Mr. Maiden exhibited a collection of Leguminosce indigenous in New South Wales, comprising 25 genera and 75 species. Of the plants collected in the immediate neighbourhood of Sydney may be mentioned Acacia hispidula, A. lunata, A. decurrens $A$. oxycedrus, Aotus lanigera, Zornia diphylla, and some interesting species of Pultencea and Oxylobium. Some of the rarer Acacias from the Western Districts were also exhibited, together with some rare species of Pultencea, Bossicea, Oxylobium, \&c., collected near the Victorian border, by Mr. Bauerlen. Each species was mounted on cardboard and full particulars given. Also plants of Myriogyne minuta, Less., a composite plant with numerous synonyms, and known in the Southern Districts as "Sneezeweed." Dr. Woolls, a few months ago, drew attention to this plant as a remedy in ophthalmia. Mr. Maiden said he would be able to give specimens of the herb to those who desired to test its properties in the direction indicated.

Mr. Fletcher exhibited for Mr. A. G. Hamilton, of Guntawang, a large and remarkable frog, at present undetermined, recently captured by his son Charles, at Hartley, Blue Mountains, where it was found buried in the sand in the bed of a creek. It differs from any Australian frog at present described, by having a row of spines on the dorsal surface of each of the first three fingers, the seventh and last spine on the first finger of each hand being conspicuously larger and more formidable than the others.

At the close of the regular business the Presidentdrew the attention of Members to a communication received from Baronv. Mueller, in which, referring to the interesting Botanical discoveries made by Messrs. W. Sayer and A. Davidson on Mount Bellenden Ker, he suggests that the Society, or Members of the Society, should make an exploration of Mount Sea-view ; stating further that he had himself as far back as 1859 sent Dr. Beckler into the Hastings River district for that purpose. This attempt proved ineffectual owing to the absence of settlement in the neighbourhood. The Council of the Society, though not able to take action at once in the matter, applied to the best authorities for information. At 
present the principal points ascertained are, by the kindness of Mr. E. Herborn, L. S. 52 Castlereagh Street-That there are two mountains called Sea-view, one so-marked on the Government Maps at the head of the Hastings, the other marked as "Kippara" near the headwater of the Yesabah Creek. Mr. Herborn had been within a few miles of the former, and on the summit of the latter, which he considers to be, probably, the highest summit in the New England Range. He is not aware that the Hastings River mountain has ever been ascended, and would not advise that the attempt should be made except by a party of experienced bushmen. It was not likely that any effort in this direction could be made during this autumn, especially after so extraordinary a rainfall as we have had. But all information on the subject would be thankfully received. 


\section{$2 \mathrm{BHL}$ Biodiversity Heritage Library}

Stephens, W J. 1887. "On some additional labyrinthodont fossils from the Hawkesbury sandstone of New South Wales." Proceedings of the Linnean Society of New South Wales 2, 1175-1195.

https://doi.org/10.5962/bhl.part.29166.

View This Item Online: https://www.biodiversitylibrary.org/item/21749

DOI: https://doi.org/10.5962/bhl.part.29166

Permalink: https://www.biodiversitylibrary.org/partpdf/29166

\section{Holding Institution}

MBLWHOI Library

\section{Sponsored by}

MBLWHOI Library

\section{Copyright \& Reuse}

Copyright Status: NOT_IN_COPYRIGHT

This document was created from content at the Biodiversity Heritage Library, the world's largest open access digital library for biodiversity literature and archives. Visit BHL at https://www.biodiversitylibrary.org. 